\title{
Spontaneous Bacterial Peritonitis in Cirrhotic Patients: Triggering Receptor Expressed on Myeloid Cells (TREM-1) as a Valid Marker
}

\author{
Nadia A Abdelkader ${ }^{1}$, Waheed Abd El Monsef ${ }^{1}$, Ahmed F Helal ${ }^{1}$, Ghada \\ A Ismail ${ }^{2}$, Dalia H Abdelhamid ${ }^{2}$, Maha M El Gaafary ${ }^{3}$, Khaled Raafat ${ }^{4}$, \\ Yasser A Abd El Razek ${ }^{1}$ and Ahmed Fouad Sherief ${ }^{1 *}$ \\ ${ }^{1}$ Tropical Medicine Department, Ain Shams University, Cairo, Egypt \\ ${ }^{2}$ Clinical Pathology Department, Ain Shams University, Cairo, Egypt \\ ${ }^{3}$ Public Health and Community Medicine, Ain Shams University, Cairo, Egypt \\ ${ }^{4}$ Internal Medicine, Gastroenterology and Hepatology, Ain Shams University, Cairo, \\ Egypt \\ *Corresponding Author: Ahmed Fouad Sherief, Tropical Medicine Department, \\ Faculty of Medicine, Ain Shams University, Abbasia, Cairo, Egypt.
}

Received: September 24, 2020

Published: October 22, 2020

(C) All rights are reserved by Ahmed Fouad

Sherief., et al.

\begin{abstract}
Purpose: Assessment of Triggering Receptor Expressed on Myeloid Cells (TREM-1) levels in the diagnosis of SBP and effectiveness of treatment among Egyptian cirrhotic ascitic patients.

Methods: This was a Prospective case-control study, which was conducted on 60 cirrhotic ascitic patients, and divided into two groups:

- Group 1: (Control) 30 cirrhotic ascitic patients without SBP

- Group 2: (SBP) 30 cirrhotic ascitic patients with SBP were admitted to the Tropical Medicine Department at Ain Shams University Hospitals with ascites due to chronic liver disease. All patients were subjected to a history of taking the clinical examination and laboratory investigations including ascitic fluid sampling for biochemical testing, total and predominant cell type, count of bacterial culture, and TREM-1 level.
\end{abstract}

Results: There was a high statistically significant difference between the two groups in the baseline level of TREM-1 while the mean was higher $1280 \mathrm{pg} / \mathrm{ml}( \pm 1136.9)$ with a level range between $(580-4500 \mathrm{pg} / \mathrm{ml})$ among patients with SBP Than the control group mean $129.9 \mathrm{pg} / \mathrm{ml}( \pm 51.9)$ with a level range between $(60-250 \mathrm{pg} / \mathrm{ml})$ among. Besides, it was found a statistically significant difference in the level of TREM-1 before and after treatment among patients with SBP. The mean of TREM-1 before treatment was higher $1280.6 \mathrm{pg} / \mathrm{ml}( \pm 1136.9)$ than a mean $376.2 \mathrm{pg} / \mathrm{ml}( \pm 78.4)$ and level range between $(260-560 \mathrm{pg} / \mathrm{ml})$ after the treatment.

Conclusion: TREM-1 is an easy, rapid, and reliable diagnostic tool for SPB which also harbors great value in following up patients with SBP.

Keywords: CLD; Ascites; Spontaneous Bacterial Peritonitis; Ascitic TREM-1 Level; Ascitic Culture

\section{Introduction}

Spontaneous bacterial peritonitis (SBP) is a grave condition that carries a very poor outcome among cirrhotic ascitic patients. SBP occurs in 10 to $30 \%$ of hospitalized cirrhotic ascitic patients [1]
Mortality may dramatically increase up to $30-50 \%$ unless proper antibiotic treatment was initiated as soon as possible [2].

Manual ascitic polymorph nuclear (PMN) count higher than 250 cells/ $\mu$ l and identifying bacteria in AF is the hallmark for di- 
agnosis of SBP. Despite the accuracy of AF culture and sensitivity in identifying the offending organism, the result of such culture may be delayed up to 5 days which in turn delays the optimum antibiotic therapy putting our patients' livers in danger. Thus, empirical antibiotic therapy is the standard approach to treatment while awaiting test results [3]. Also, manual measurement of PMN count is operator dependent which makes quality control difficult and can delay the diagnosis [4].

Recent different studies evaluated the validity and utility of ascitic fluid triggering receptors expressed on myeloid cells-1 (TREM-1) levels as a tool for early diagnosis of SBP. Triggering receptors expressed on myeloid cells-1 is a receptor expressed and released by innate inflammatory cells after exposure to bacteria membrane components [5].

TREM proteins are a family of immune-regulatory receptors expressed broadly on innate immune cells. TREM proteins are type I transmembrane receptors containing a single immunoglobulin variable domain [6].

TREM-1 is an important regulator in innate immunity; it amplifies inflammation in response to infection. Activation of TREM-1 on monocytes by agonistic antibodies in the presence of TLR (Toll-like receptor) ligands synergistically increases the production of proinflammatory chemokines and cytokines and decreases the production of anti-inflammatory IL-10 [7]. During infection by Grampositive and Gram-negative bacteria and fungi, the expression of membrane-bound TREM-1 is highly up-regulated [8]. A soluble form of TREM-1 is also released from cells and can be measured in biological fluids [9].

The study of TREM-1 in acute stages of certain infections may be correlated to the severity and prognosis of sepsis up to septic shock $[10,11]$.

\section{Aim of the Work}

Assessment of triggering receptor expressed on myeloid cells (TREM-1) in the diagnosis of SBP and effectiveness of treatment among Egyptian cirrhotic ascitic patients.

\section{Patients and Methods}

This study was a prospective case-control study, performed in the Tropical medicine department Ain Shams University hospitals by Ascites Study Group affiliated to the Egyptian Club of Ascites
(ECA) over six months on 60 patients with chronic liver disease and ascites. Patients were divided into two groups Group 1: 30 ascitic patients without SBP and group 2: 30 ascitic patients with SBP.

\section{Methods}

All patients were subjected to full history taking, thorough clinical examination, and full laboratory investigations including complete blood picture with differential PNL count, liver, and renal profiles. ESR and CRP, viral markers: HCV Ab and HBs Ag. The study protocol was approved by the Ethical Committee of Faculty of Medicine, Ain shams university. Informed written consent was obtained from each subject by the recommendation of the revised Declaration of Helsinki.

On admission samples from ascitic fluid were collected under complete aseptic condition before the start of antimicrobial treatment for the patients, by withdrawing three ascitic samples, every $10 \mathrm{ml}$ by a sterile syringe, and the following tests were done: Biochemical testing, total and predominant cell type count, bacterial culture (upon which the SBP was diagnosed) ascitic TREM-1 was analyzed and determined using enzyme-linked immunosorbent assay (ELISA) kits from R\&D Systems (USA) by the recommendation of the manufacturer's instructions.

Data were collected and statistically analyzed

Data were collected and recorded on specific forms. Analysis of data was done using SPSS (Statistical Package for Social Science) program version 18 . To describe the studied sample, quantitative data e.g. age were presented as a minimum, maximum, mean, and standard deviation. Qualitative data e.g. sex were presented as count and percentage.

\section{Statistical methods}

One-way ANOVA test was used to compare quantitative data between different groups then the Post Hoc test was used to detect the difference between individual groups. A Chi-Square test was used to compare qualitative data between different groups. P-value $<0.05$ was considered statistically significant.

\section{Results}

This case-control study included 60 ascitic patients with CLD,30 patients without SBP (control, group 1), and 30 patients with SBP (group 2). All cases of CLD were diagnosed according to clinical, biochemical, and/or imaging findings. 
Spontaneous Bacterial Peritonitis in Cirrhotic Patients: Triggering Receptor Expressed on Myeloid Cells (TREM-1) as a Valid Marker

Table 1 results show a significant difference in the Child Class and MELD Score between the two groups to be more child $\mathrm{C}$ and elevated MELD score in the SBP group.

\begin{tabular}{|l|c|c|c|}
\hline Parameter & Control & SBP & P-value \\
\hline Child Class: N (\%) & & & $0.036^{*}$ \\
B & $17(56.7)$ & $8(26.7)$ & \\
C & $13(43.3)$ & $22(73.3)$ & \\
\hline MELD Score & & & \\
Mean ( \pm SD) & $14.5(4.6)$ & $18.8(7.2)$ & $0.009^{*}$ \\
\hline
\end{tabular}

Table 1: The child class and MELD score in the study groups.

* Significant difference.

This table 2 shows the significant difference between the two groups regarding ascitic fluid albumin, $\mathrm{LDH}$, and cell count to be higher in the SBP group with lower albumin levels.

\begin{tabular}{|l|c|c|c|}
\hline Parameter & $\begin{array}{c}\text { Control } \\
\text { Mean (SD) }\end{array}$ & $\begin{array}{c}\text { SBP } \\
\text { Mean (SD) }\end{array}$ & P-value \\
\hline Protein (g/dl) & $1.427(.7007)$ & $1.370(.4519)$ & 0.771 \\
\hline Albumin(g/dl) & $0.713(.383)$ & $0.540(.354)$ & $0.001^{*}$ \\
\hline $\begin{array}{l}\text { Glucose (mg/dl) } \\
70-100 \mathrm{mg} / \mathrm{dl}\end{array}$ & $120.21(48.20)$ & $114.594(21.01)$ & 0.765 \\
\hline LDH (IU/L) & $74.03(57.382)$ & $176.37(92.274)$ & $<0.001^{*}$ \\
\hline $\begin{array}{l}\text { Ascitic fluid cell } \\
\text { count }(<250 \\
\left.\text { cell/mm } \mathrm{mm}^{3}\right)\end{array}$ & $60.10(4.327)$ & $560.85(860.67)$ & $<0.001^{*}$ \\
\hline
\end{tabular}

Table 2: The baseline ascitic fluid analysis in the two groups.

* Significant difference.

Table 3 and 4 shows that there was a highly significant difference between the two groups in the base level of TREM-1 in which the mean was $(12801 \pm 1136.9 \mathrm{pg} / \mathrm{ml})$ with a level range between (580-4500 pg/ml) in SBP versus mean $(129.95 \pm 1.9 \mathrm{pg} / \mathrm{ml})$ with a level range between $(60-250 \mathrm{pg} / \mathrm{ml})$ in the control group, this result supports the validity of TREM-1 in the diagnosis of SBP.

\begin{tabular}{|l|c|c|c|}
\hline TREM (pg/ml) & Control & SBP & P-value \\
\cline { 1 - 3 } Mean $( \pm$ SD) & $129.9(51.9)$ & $1280(1136.9)$ & $<0.001^{*}$ \\
\cline { 1 - 3 } Min - Max & $60-250$ & $580-4500$ & \\
\hline
\end{tabular}

Table 3: The baseline level of TREM-1 in the two groups.

\begin{tabular}{|l|c|c|c|}
\hline & \multicolumn{2}{|c|}{ TREM (pg/ml) } & \multirow{2}{*}{ P-value } \\
\hline & Before TTT & After TTT & \\
\cline { 1 - 3 } Mean (SD) & $1280.6(1136.9)$ & $376.2(78.4)$ & \multirow{2}{*}{$0.001^{*}$} \\
\cline { 1 - 3 } Min - Max & $580-4500$ & $260-560$ & \\
\hline
\end{tabular}

Table 4: The level of TREM-1 before and after treatment start in the SBP group.

* Significant difference.

Also, there is a significant difference in the measurement of TREM-1 before and after treatment in the SBP patients in which the mean of TREM-1 before treatment was $(1280.6 \pm 1136.9 \mathrm{pg} / \mathrm{ml})$ with a level range between (580 - $4500 \mathrm{pg} / \mathrm{ml})$ versus mean $(376.2$ $\pm 78.4 \mathrm{pg} / \mathrm{ml}$ ) and level range between (260 - $560 \mathrm{pg} / \mathrm{ml})$ after the treatment. This result supports the prognostic value of TREM-1 in follow up the SBP patient.

\section{Discussion}

Spontaneous bacterial peritonitis (SBP) is considered to be a grave medical condition among cirrhotic ascitic patients [12], which carries a very poor prognosis with an overall estimated mortality of $20-40 \%$ [12]. The severity of complications of such conditions sparked different studies to find an accurate, rapid and feasible tool for diagnosis and hence optimum management [12].

Our study enrolled 60 cirrhotic ascitic patients. They were divided into two groups according to whether they have SBP or not.

Child-Pugh's classification was the main scoring system upon which we relied to classify our patients into classes A, B, and C. where no patients were class $A$ in both groups. Twenty-two patients' $(73.3 \%)$ among the SBP group versus 13 patients in the other group (43.3\%) were in child-Paugh class C.

Such a high frequency of Child class $\mathrm{C}$ among the patients with SBP $(73.3 \%)$ was comparable to $66 \%$ in previous the study conducted by Ichou and his colleagues [13], and 55\% in another study [14]. This can be attributed to severely deteriorated liver functions including coagulopathy, hyper-bilirubinemia, and hypoalbuminemia which are pivotal factors for ascitic fluid infection in patients with chronic liver disease and ascites [15].

In the current study, the mean of MELD score in the control group of patients was $(14.5 \pm 4.6)$, while in patients with SBP was

Citation: Ahmed Fouad Sherief., et al. "Spontaneous Bacterial Peritonitis in Cirrhotic Patients: Triggering Receptor Expressed on Myeloid Cells (TREM-1) as a Valid Marker". Acta Scientific Gastrointestinal Disorders 3.11 (2020): 23-27. 
Spontaneous Bacterial Peritonitis in Cirrhotic Patients: Triggering Receptor Expressed on Myeloid Cells (TREM-1) as a Valid Marker

(18.8 \pm 7.2$)$, such finding is in line with previous studies which also reported higher MELD score in the SBP group of patients $[15,16]$.

Regarding ascitic fluid chemistry among the SBP group; the mean LDH level was $176.3 \pm 92.2 \mathrm{IU} / \mathrm{L}$, total protein was $1.37 \pm 045$ $\mathrm{g} / \mathrm{dl}$, albumin was $0.54 \pm 0.35 \mathrm{~g} / \mathrm{dl}$. The current results are nearly similar to what different studies reported, where the mean ascitic fluid protein was $1.3 \pm 0.5 \mathrm{~g} / \mathrm{dl}$, albumin was $0.5 \pm 0.2 \mathrm{~g} / \mathrm{dl}$ in patients with AFI in different studies $[15,18]$.

The ascitic culture and sensitivity done for the studied patients were negative among all patient in the control group with ascitic fluid cell count less than 250 cells $/ \mathrm{mm}^{3}$, while in SBP group showed that 18 patients had culture-negative neutrocytic ascites (60\%) and 12 patients had mono-microbial bacterascites (40\%) [19,20]. The most frequently isolated micro-organisms were E. coli $(25 \%)(3 / 12$ culture-positive patients and Klebsiella (16.7\%). The antimicrobial Ceftriaxone was the most frequent antimicrobial detected in the sensitivity test (54.5\%). These results were consistent with Such and colleagues who reported that the most frequently isolated micro-organisms are E. coli (45\%) and Klebsiella spp. (11\%). Also Amoako and Kofi in their study The major isolates from the positive cultures were Escherichia coli $(5 / 9,55.6 \%)$ and Klebsiella spp. (2/9, $22.2 \%)[20,21]$.

The current study showed that there was a high statistically significant difference between the two groups in the base level of TREM-1 in which the mean was $(1280+/-1136.9 \mathrm{pg} / \mathrm{ml})$ with a level range between ( $580-4500 \mathrm{pg} / \mathrm{ml})$ in SBP versus mean (129.9 $+/-51.9 \mathrm{pg} / \mathrm{ml}$ ) with a level range between $(60-250 \mathrm{pg} / \mathrm{ml})$ in the control group, this result was consisted with Ichou and his colleagues who reported that TREM-1 concentration was significantly higher in SBP samples $4456 \mathrm{pg} / \mathrm{ml}$ (3351 - $5498 \mathrm{pg} / \mathrm{ml}$ ) versus the non-SBP samples $642 \mathrm{pg} / \mathrm{ml}$ (417 - $899 \mathrm{pg} / \mathrm{ml}$ ). This result supports the validity of TREM-1 in the diagnosis of SBP [14].

Also, this study showed a statistically significant difference in the level of TREM-1 before and after treatment in the SBP patients in which the mean of TREM-1 before treatment was (1280.6 +/$1136.9 \mathrm{pg} / \mathrm{ml})$ versus mean $(376.2+/-78.4 \mathrm{pg} / \mathrm{ml})$ and after the treatment, this result supports the prognostic value of TREM-1 in the follow up of the response to treatment of SBP patients.

Another significant positive correlation was found between the TREM-1 level and refractory ascites. The mean of TREM-1 in refrac- tory ascites patient was 1535.4 versus the mean of 771 in patients with ascites responding to diuretics, such differences had high statistical significance. Also, TREM-1 Level was found to be related to elevated ascitic neutrophils cell count which may contribute to a decline in its level after receiving proper treatment for SBP. Also, the presence of higher TREM-1 level was found to be in patients with a previous history of SBP (2215.56 +/- $1728.40 \mathrm{pg} / \mathrm{ml})$ compared to those with no history of previous attacks of SBP.

The later points of discovered results regarding the prognostic value of the TREM-1 level could be the point of research shortly.

\section{Conclusion}

TREM-1 is an easy, rapid, and reliable diagnostic tool for SPB which also harbors great value in following up patients with SBP. However further studies on a larger scale of patients are needed to confirm its sensitivity and specificity.

\section{Conflict of Interest}

On behalf of all authors, the corresponding author states that there is no conflict of interest.

\section{Bibliography}

1. Rimola A., et al. "Diagnosis, treatment, and prophylaxis of spontaneous bacterial peritonitis: a consensus document. International Ascites Club". Journal of Hepatology 32.1(2000): 142-153.

2. Garcia-Tsao G. "Current management of the complications of cirrhosis and portal hypertension: Variceal hemorrhage, ascites, and spontaneous bacterial peritonitis". Gastroenterology 120.3(2001): 726-748.

3. Sugihara T., et al. "Rapid identification of bacterial species with bacterial DNA microarray in cirrhotic patients with spontaneous bacterial peritonitis". Internal Medicine 48.1 (2009): 3-10.

4. Runyon BA. "Management of adult patients with ascites due to cirrhosis". Hepatology 39.3 (2004): 841-856.

5. Bouchon A., et al. "TREM-1 amplifies inflammation and is a crucial mediator of septic shock". Nature 410 (2001): 1103. 
6. Allcock RJN., et al. "The human TREM gene cluster at $6 \mathrm{p} 21.1$ encodes both activating and inhibitory single IgV domain receptors and includes NKp44". European Journal of Immunology 33.2 (2003): 567-577.

7. Arts RJW., et al. "TREM-1: intracellular signaling pathways and interaction with pattern recognition receptors". Journal of Leukocyte Biology 93.2 (2013): 209-215.

8. Begum NA., et al. "Mycobacterium Bovis BCG Cell Wall-Specific Differentially Expressed Genes Identified by Differential Display and cDNA Subtraction in Human Macrophages". Infection and Immunity 72.2 (2004): 937-948.

9. Gibot S., et al. "A Soluble Form of the Triggering Receptor Expressed on Myeloid Cells-1 Modulates the Inflammatory Response in Murine Sepsis". The Journal of Experimental Medicine 200.11 (2004): 1419-1426.

10. Ford JW and McVicar DW. "TREM and TREMlike receptors in inflammation and disease". Current Opinion on Immunology 21.1 (2009): 38-46.

11. Gomez-Pina V., et al. "Metalloproteinases shed TREM-1 ectodomain from lipopolysaccharide-stimulated human monocytes". Journal of Immunology 179.6 (2007): 4065-4073.

12. Mowa CT and Stanley AJ. "Review article: spontaneous bacterial peritonitis-diagnosis treatment and prevention". Aliment Pharmacology Therapy 15.12 (2001): 1851-1859.

13. Ogutu EO. "Spontaneous bacterial peritonitis in patients with liver diseases and ascites as seen at Kenyatta National Hospital". East African Medical Journal 4 (1988): 547-551.

14. Ichou L., et al. "Ascitic fluid TREM-1 for the diagnosis of spontaneous bacterial peritonitis". Gut 65.3 (2016): 536-538.

15. Badran E. "Identification of bacterial pathogens in ascitic fluid from cirrhotic Egyptian patients by use of microbiological culture and PCR based methods". (Thesis for MD degree of Tropical Medicine. Under the supervision of AlNaggar M, Abdella H, and Hefny Z (2017).
16. Gines P., et al. "Management of cirrhosis and ascites". The New England Journal of Medicine 350 (2004): 1646-1654.

17. Kimmann M., et al. "Sustained impact of nosocomial-acquired spontaneous bacterial peritonitis in different stages of decompensated liver cirrhosis". PLoS One 14.8 (2019): e0220666.

18. Mostafa MS., et al. "Detection of ascitic fluid infections in patients with liver cirrhosis and ascites". Arabian Journal of Gastroenterology 12.1 (2011): 20-24.

19. Enomoto H., et al. "Diagnosis of spontaneous bacterial peritonitis and an in situ hybridization approach to detect an "unidentified" pathogen". International Journal of Hepatology (2014): 634617.

20. Amoako Duah and Kofi Nyaako Nkrumah. "Prevalence and predictors for spontaneous bacterial peritonitis in cirrhotic patients with ascites admitted at the medical block in KorleBu Teaching Hospital, Ghana". Pan African Medical Journal 33 (2019): 35.

21. Such J., et al. "Pathogenesis and clinical feature of spontaneous bacterial peritonitis". In G. P. In: Arroyo V, Rodes J, Schrier RW, eds. (Ed.), Ascites and Renal Dysfunction in Liver Disease $2^{\text {nd }}$ edition. (2005): 422-434.

\section{Assets from publication with us}

- Prompt Acknowledgement after receiving the article

- Thorough Double blinded peer review

- Rapid Publication

- Issue of Publication Certificate

- High visibility of your Published work

Website: www.actascientific.com/

Submit Article: www.actascientific.com/submission.php

Email us: editor@actascientific.com

Contact us: +919182824667 
Spontaneous Bacterial Peritonitis in Cirrhotic Patients: Triggering Receptor Expressed on Myeloid Cells (TREM-1) as a Valid Marker

Citation: Ahmed Fouad Sherief., et al. "Spontaneous Bacterial Peritonitis in Cirrhotic Patients: Triggering Receptor Expressed on Myeloid Cells (TREM-1) as a Valid Marker". Acta Scientific Gastrointestinal Disorders 3.11 (2020). 